\title{
Individuele verschillen in werkplekleren bij leraren in opleiding: een kwestie van motivatie?
}

\author{
Eva Kyndt, Vincent Donche, David Gijbels, Eveline Mertens \& Peter Van Petegem ${ }^{*}$
}

\begin{abstract}
In deze studie worden individuele verschillen in leren bij studenten in de lerarenopleiding die stage lopen in kaart gebracht aan de hand van het referentiekader van Oosterheert (2001). Daarnaast wordt de relatie tussen deze kenmerken van leren en motivatie verkend vanuit de prestatiedoelentheorie. De resultaten tonen aan dat studenten in stages het leren onderwijzen zien als 'lesgeven en uitproberen', maar kennelijk ook veel behoefte hebben aan ondersteuning door anderen. Ze stappen op hun mentor en collega's af en kijken naar hun leerlingen om hun eigen lessen te evalueren. Negatieve leservaringen vormen voor hen geen bron van informatie maar eerder een bezorgdheid. Hoe studenten leren in stages hangt matig samen met hun motivatie voor leren. Er treden vooral verschillen op in stageleren naargelang de afstudeerrichting die studenten volgen. Implicaties voor onderzoek en praktijk worden toegelicht.
\end{abstract}

\section{Inleiding}

Over de wijze waarop studenten leren in het eerste jaar van het hoger onderwijs is reeds veel bekend. Eerder onderzoek wijst op het belang van leerstrategieën die studenten volgen in schoolse leercontexten (bijv. Baeten, Kyndt, Struyven, \& Dochy, 2010; Gijbels, Donche, Richardson, \& Vermunt, 2014). Hoe studenten omgaan met leren is in belangrijke mate verbonden met hun intenties of motivatie voor leren. Zo verwerken studenten leerinhouden op meer diepgaande wijze wanneer zij het leren sterker vanuit interne dan externe drijfveren motiveren. Het omgekeerde geldt vaak bij studenten die op een meer oppervlakkige wijze studeren (Donche, De Maeyer, Coertjens, Van Daal, \& Van Petegem, 2013).

Veel minder is bekend over de verschillen tussen eerstejaarsstudenten voor wat de kwaliteit van leren in niet-schoolse leercontexten (bijv. stages) betreft. In deze meer authentieke leercontexten nemen studenten actief deel aan vormen van praktijkleren en is er vaak meer sprake van zelfsturing, samenwerking en auto-

* $\quad$ Prof. Dr. E. Kyndt is werkzaam bij het Centrum voor professionele opleiding \& ontwikkeling, en levenslang leren (KU Leuven, België). Eva.kyndt@ppw.kuleuven.be Prof. Dr. Vincent Donche is werkzaam bij het Instituut voor Onderwijs en Informatiewetenschappen (Universiteit Antwerpen, België) Vincent.Donche@ua.ac.be Prof. Dr. David Gijbels is werkzaam bij het Instituut voor Onderwijs en Informatiewetenschappen (Universiteit Antwerpen, België). David.Gijbels@ua.ac.be Mevr. Eveline Mertens is werkzaam binnen de lerarenopleiding van de Karel de Grote Hogeschool, Antwerpen, België. Eveline.Mertens@Kdg.be Prof. Dr. Peter Van Petegem is werkzaam bij het Instituut voor Onderwijs en Informatiewetenschappen (Universiteit Antwerpen, België). Peter.vanpetegem@ua.ac.be 
nomie in vergelijking met traditionele leercontexten (bijv. Donche et al., 2012). In heel wat bacheloropleidingen in Vlaanderen nemen deze niet-schoolse leercontexten toe. Deze toename maakt het ook noodzakelijk dat er inzicht is in hoe kwalitatieve verschillen in leren optreden bij studenten die stage lopen en welke factoren hierin een rol spelen.

In deze studie gaan we na hoe eerstejaarsstudenten verschillen in leren tijdens het stage lopen en de mogelijke rol die studiemotivatie hierin speelt. Een context waarin het stageleren reeds vanaf het eerste opleidingsjaar aan belang wint, is de reguliere bachelorlerarenopleiding in Vlaanderen. Individuele verschillen in stageleren worden in deze studie verkend aan de hand van het model van Oosterheert (2001) inzake leren onderwijzen. Hierbij gaat zowel aandacht uit naar de mogelijke verschillen in leerconcepties of leeropvattingen waarover eerstejaarsstudenten beschikken als naar de concrete cognitieve en regulatieve leeractiviteiten die worden ondernomen tijdens stages. Tevens beogen we dit bestaande model verder uit te breiden door ook aandacht te besteden aan de mogelijke samenhang met motivatie. Naar analogie met het onderzoek naar het leren in formele contexten verwachten we een samenhang tussen kwalitatieve verschillen in stageleren en motivatie. In wat volgt, lichten we het theoretische raamwerk van deze studie verder toe.

\section{Werkplekleren in de lerarenopleiding}

Eerder onderzoek toont aan dat studenten op verschillende manieren leren en dat persoons- en omgevingsgebonden kenmerken een invloed uitoefenen (bijv. Donche \& Van Petegem, 2005; Endedijk \& Vermunt, 2013; Kyndt, Dochy, Struyven, \& Cascallar, 2012). Heel wat bestaande modellen over het leren van studenten in schoolse contexten negeren echter grotendeels dat studenten in verschillende opleidingen ook leren uit de ervaringen die ze opdoen tijdens verschillende vormen van werkplekleren (Endedijk, Donche, \& Oosterheert, 2014). In nagenoeg alle lerarenopleidingen leren studenten door een combinatie van theorie en praktische ervaringen. In eerder onderzoek wees Oosterheert op een aantal belangrijke kwalitatieve verschillen in stageleren op het vlak van leerconcepties, cognitieve en regulatieve activiteiten alsook emotieregulatie (Oosterheert, 2001; Oosterheert, Vermunt, \& Denessen, 2002).

\section{Leerconcepties}

Leerconcepties omvatten opvattingen die studenten hebben over het proces van leren onderwijzen. Binnen deze leerconcepties worden drie dimensies onderscheiden. Een eerste dimensie is 'lesgeven en uitproberen'. Studenten die hoog scoren op deze dimensie zien leren onderwijzen als uittesten en proberen; ze verwachten dan ook vooral concrete en praktische tips van hun mentor. Een tweede dimensie omvat het verhogen van het bewustzijn onder 'externe controle'. Dit betekent dat studenten andere personen nodig hebben die hen helpen om zich bewust te worden van bepaalde gedragingen en interpretaties van lesgeven. De derde en laatste 
leerconceptie verwijst naar de zelfregulatie van de student. Deze dimensie brengt in kaart hoe studenten zelf hun leerdoelen en -processen bepalen, wat als meer wenselijk kan worden beschouwd (Donche \& Van Petegem, 2005).

\section{Cognitieve en regulatieve leeractiviteiten}

Hierbij gaat het om het gedrag van studenten of de leeractiviteiten die ze ondernemen tijdens de stage. Vijf verschillende leerdimensies worden onderscheiden. De eerste dimensie betreft 'een proactief en breed gebruik van de mentor'. Dit omvat activiteiten van studenten gericht naar hun mentor zoals het vragen naar praktische tips, interpretaties van lessituaties of beoordelingen van prestaties. Een tweede dimensie omvat het 'onafhankelijk zoeken naar conceptuele informatie'. Hierbij zoeken studenten op zelfstandig wijze naar antwoorden op hun vragen en consulteren zij verschillende informatiebronnen. De derde dimensie 'actief relateren van theorie en praktijk' sluit hierbij aan en verwijst naar het bewust gebruik van conceptuele informatie om op de eigen leservaringen te reflecteren om zo het lesgeven te verbeteren. De vierde dimensie betreft 'het ontwikkelen van een visie door middel van discussie' en omvat alle activiteiten waarbij de student doelbewust (ervaren) collega's benadert voor zowel praktische tips als inspiratie voor en feedback bij het ontwikkelen van een eigen visie op lesgeven. De vijfde dimensie spitst zich toe op een aantal leerlinggerichte criteria die studenten hanteren om hun eigen lesgeven te evalueren zoals bijvoorbeeld de gepercipieerde motivatie of vooruitgang van de leerlingen.

\section{Emotieregulatie}

Hierbij gaat het om verschillen die optreden in emotieregulatie bij een negatieve leservaring tijdens het stage lopen. Twee dimensies maken deel uit van deze component: 'vermijding' en 'bezorgdheid'. Een hoge score op emotievermijding betekent dat slechte leservaringen niet als een belangrijke bron van informatie worden gezien. De tweede dimensie verwijst naar hoe bezorgd studenten zijn over hun slechte leservaringen en hierbij behoefte hebben aan steun van anderen om onzekerheden weg te nemen.

\section{Doeloriëntatie}

Eerder onderzoek wees uit dat de prestatiedoelentheorie een interessant referentiekader kan zijn om verschillen in motivatie in zowel schoolse als werkplekcontexten te duiden (bijv. Elliot \& McGregor, 2001; Nitsche, Dickhaüser, Fasching, \& Dresel, 2011). Doeloriëntaties worden omschreven als relatief stabiele motivationele oriëntaties die het leergedrag aansturen in omgevingen die een prestatie verwachten (Nitsche et al., 2011). Individuele doeloriëntaties representeren het individuele streven, het doel waarop iemand zich richt. Er wordt een onderscheid gemaakt tussen een leerdoeloriëntatie en een prestatiedoeloriëntatie. Individuen met een leerdoeloriëntatie streven ernaar hun kennis en vaardigheden of competenties te verhogen, terwijl individuen met prestatiedoelen ernaar streven hun superieure competenties ten opzichte van anderen te 
demonstreren of hun gebrek aan competenties te verbergen (Elliot \& McGregor, 2001; Nitsche et al., 2011). Prestatiedoelen bevatten aldus een normatieve component (Elliot \& McGregor, 2001). Eerder onderzoek wees ook uit dat prestatiedoelen verder onderverdeeld kunnen worden in prestatietoenaderingsdoelen (demonstreren competenties) en prestatievermijdingsdoelen (verbergen van een gebrek aan competenties) (Nitsche et al., 2011).

Over de relatie tussen het leren in stagecontexten en studiemotivatie is weinig bekend (Endedijk \& Vermunt, 2013). Studies waarin praktijkleren werd gekoppeld aan verschillen in motivatie leveren wel indicaties op. Studenten met een hogere leerdoeloriëntatie tijdens de stage blijken doorgaans meer zelfgereguleerd leergedrag te vertonen en meer samen te werken met collega's (Donche, Gijbels, Van den Bossche, Van Petegem, \& Ilsbroux, 2011). Volgens het onderzoek van Nitsche et al. (2011) zouden leerkrachten die ernaar streven hun pedagogische bekwaamheid te verhogen frequenter gebruik maken van verschillende leermogelijkheden (bijv. lid zijn van bepaalde gemeenschappen of teams, deelnemen aan opleidingen of het bespreken van bepaalde zaken met collega's). Berger (2012) stelde ook vast dat het zinvol is om de combinatie van leer- en prestatiedoelen nader te onderzoeken en mogelijk te relateren aan verschillen in leren. Zo kon worden aangetoond dat een profiel dat laag scoort op leerdoelen en hoog scoort op werkvermijdingsdoelen, minder gebruikt maakt van diepgaand en zelfgestuurd leren. Wie hoog scoort op leerdoelen en laag op prestatiedoelen en werkvermijdingsdoelen zou meer gebruik maken van diepgaand en zelfgestuurd leren, en minder op oppervlakkige wijzen leerinhouden verwerken

Op basis van het kader van Oosterheert (2001) verwachten we dat een leerdoeloriëntatie positief zal samenhangen met 'zelfbepaling', 'het ontwikkelen van een visie door middel van discussie', 'een proactief, breed gebruik van de mentor', 'een onafhankelijke zoektocht naar conceptuele info' en 'het actief relateren van theorie en praktijk'. Er kan ook worden verwacht dat leerdoeloriëntatie negatief zal samenhangen met vermijdingsgedrag, aangezien negatieve leservaringen ook een bron van leren kunnen zijn. Een prestatiedoeloriëntatie hangt mogelijk meer samen met andere kenmerken van leren onderwijzen zoals 'lesgeven en proberen', 'externe controle' en 'leerlinggerichte evaluatiecriteria'. Voorts nemen we in deze studie aan dat studenten meerdere doelen kunnen combineren (leerdoelen én prestatiedoelen) en zullen we de relatie met kenmerken van stageleren onderzoeken vanuit het meerdoelenperspectief (zie ook Pastor, Barron, Miller, \& Davis, 2007). Dit betekent dat in een eerste stap wordt nagegaan of er verschillende motivatieprofielen zoals onder anderen Berger (2012) ze omschrijft, bij de studenten te onderscheiden zijn. In een tweede stap wordt vervolgens het verband tussen deze motivatieprofielen en kenmerken van leren onderwijzen onderzocht.

\section{Onderzoeksvragen}

In deze studie beogen we, ten eerste, individuele verschillen in leren onderwijzen in kaart brengen van studenten die stage lopen in het eerste jaar van de leraren- 
opleiding. Ten tweede willen we nagaan of deze verschillen in leren samenhangen met het type stagecontext dat in de verschillende afstudeerrichtingen in de lerarenopleiding wordt aangeboden. De stage in de afstudeerrichting kleuteronderwijs behelst, naast een week observatie en participatie, ook twee weken voor de klas staan. De stage omvat acht studiepunten van het programma. In de afstudeerrichting lager onderwijs staan de studenten anderhalve week voor de klas samen met een medestudent. Vooraf krijgen de studenten ook de kans om te observeren en te participeren gedurende één week. Ook hier omvat de stage acht studiepunten. De stage in het secundair onderwijs is goed voor negen studiepunten van het programma en omvat de observatie van vijftien lesuren en vier lesuren voor de klas staan. Ten derde verkennen we het mogelijke verband tussen de mogelijke motivatieprofielen van studenten en het leren onderwijzen tijdens de stage. Drie onderzoeksvragen staan centraal:

- Welke leerconcepties, leeractiviteiten en emotieregulatiestrategieën worden onderscheiden bij studenten in het eerste jaar van hun lerarenopleiding?

- Zijn er verschillen inzake leerconcepties, leeractiviteiten en emotieregulatiestrategieën die studenten uit de verschillende afstudeerrichtingen hanteren?

- Kunnen er verschillende motivatieprofielen onderscheiden worden? Zo ja, verschillen deze motivatieprofielen van elkaar inzake leerconcepties, leeractiviteiten en emotieregulatie?

\section{Methode}

\section{Deelnemers}

In het totaal namen 464 eerstejaarsstudenten deel, uit een Vlaamse professionele bachelorlerarenopleiding, die stage liepen in het academiejaar 2011-2012. De drie mogelijke afstudeerrichtingen waren vertegenwoordigd: kleuteronderwijs $(n=80)$, lager onderwijs $(n=194)$ en secundair onderwijs $(n=187$, richting onbekend: $n=3)$. De meerderheid van de deelnemers was vrouwelijk $(n=326)$. De gemiddelde leeftijd was 19,82 jaar (SD = 2.68).

\section{Instrumenten}

Het 'leren van studenten tijdens stages' werd gemeten via de 'Inventory Learning to Teach Process' (ILTP; Oosterheert, 2001), die reeds is gevalideerd in Vlaanderen (Donche \& Van Petegem, 2005). Deze vragenlijst bestaat uit tien schalen (55 items), die de hiervoor omschreven verschillen in leerconcepties, leeractiviteiten en emotieregulatie in kaart brengen.

De 'doeloriëntaties' van de studenten werden gemeten door middel van de 'Achievement Goal Questionnaire' (Elliot \& McGregor, 2001; Meece, Blumenfeld, \& Hoyle, 1988). Deze vragenlijst omvat zestien items die drie schalen vormen: leerdoelen, prestatietoenaderingsdoelen en prestatievermijdingsdoelen.

\section{Data-analyses}

$\mathrm{Na}$ het vaststellen van de interne consistentie van de schaal als indicator voor betrouwbaarheid werden beschrijvende statistieken berekend, dit als antwoord 
op de eerste onderzoeksvraag. Om het verband tussen de doeloriëntatie van studenten en hoe ze leren tijdens hun stage na te gaan, werd in een eerste stap een latente profielenanalyse uitgevoerd op basis van de drie doeloriëntatieschalen. Dit gebeurde via het R-pakket MClust. Deze analysetechniek maakt het mogelijk om motivatieprofielen op basis van meer motivatiedimensies te onderscheiden (Pastor, Barron, Miller, \& Davis, 2007). In een tweede stap werden de profielen verkregen uit deze analyse en de studenten uit de drie afstudeerrichtingen met elkaar vergeleken door middel van twee-factor ANOVA-analyses, waarin zowel de twee hoofdeffecten als het interactie-effect werden nagegaan. Indien een significant verschil werd gevonden, werd een Tukey post-hoc test uitgevoerd om na te gaan welke groepen van elkaar verschilden. Alle analyses werden uitgevoerd met behulp van het R-softwarepakket (R Development Core Team, 2012).

\section{Resultaten}

\section{Kenmerken van leren onderwijzen}

Met uitzondering van de schaal 'zelfbepaling' (net onder de grens van 0,60), blijken alle ILTP-schalen voldoende intern consistent en geschikt voor verdere analyses. De gemiddelde scores op de verschillende leerconcepties (tabel 1) laten zien dat de studenten in de lerarenopleiding leren onderwijzen vooral zien als 'lesgeven en proberen'. Daarnaast scoren ze relatief hoog op het verhogen van bewustzijn onder externe controle. De score op zelfbepaling ligt lager, maar hier kan wel opgemerkt worden dat de standaardafwijking hoger is dan bij de andere twee dimensies, wat erop wijst dat er grotere verschillen zijn tussen de studenten. Wat de leeractiviteiten betreft tonen de resultaten dat studenten gemiddeld tot hoog scoren op alle leeractiviteiten. Studenten scoren het hoogst op 'leerlinggerichte evaluatiecriteria', 'proactief en breed gebruik van de mentor' en 'actief relateren van theorie en praktijk'. De scores op 'onafhankelijk zoeken naar conceptuele info' en 'ontwikkelen van een visie door middel van discussie' zijn lager maar vertonen een grotere standaardafwijking. Verder blijkt uit de resultaten dat studenten negatieve leservaringen niet zien als een bron om uit te leren (aangegeven door de lage score op emotievermijding), maar dat ze zich hier wel zorgen om maken. Ook hier treedt een grotere standaardafwijking op in vergelijking met de andere schalen.

De resultaten tonen aan dat studenten het leren onderwijzen vooral beschouwen als 'uitproberen in de praktijk' en hierbij het liefst een beroep willen doen op de hulp van anderen. Ze stappen naar hun mentor en collega's en kijken naar hun leerlingen om hun eigen lesgeven te evalueren. Daarnaast zien ze negatieve leservaringen niet als een bron van informatie, maar zijn ze er eerder bezorgd over en hebben ze anderen nodig om hen gerust te stellen. 
Tabel 1 Beschrijvende statistieken en interne consistentie

\begin{tabular}{lllll}
\hline Schaal & N & M & SD & $\begin{array}{c}\text { Cron- } \\
\text { bachs } \alpha\end{array}$ \\
\hline Concepties & & & & \\
Lesgeven en proberen & 436 & 5.13 & .72 & .75 \\
Externe controle & 446 & 4.99 & .55 & .68 \\
Zelfbepaling & 449 & 3.57 & 1.04 & .59 \\
Activiteiten & & & & \\
Proactief, breed gebruik van de mentor & 442 & 5.43 & .83 & .61 \\
Onafhankelijk zoeken naar conceptuele informatie & 439 & 3.98 & 1.10 & .74 \\
Actief theorie en praktijk relateren & 446 & 4.83 & .89 & .67 \\
Ontwikkelen visie d.m.v. discussie & 446 & 3.26 & 1.32 & .62 \\
Leerlinggerichte evaluatiecriteria & 447 & 5.81 & .74 & .72 \\
Emotieregulatie & & & & \\
Vermijding & 439 & 1.94 & .76 & .78 \\
Bezorgdheid & 448 & 4.80 & 1.19 & .72 \\
Doeloriëntatie & & & & \\
Leerdoelen & 445 & 5.43 & .62 & .70 \\
Prestatievermijdingsdoelen & 436 & 3.41 & 1.08 & .69 \\
Prestatietoenaderingsdoelen & 448 & 4.15 & 1.22 & .80 \\
\hline & & & & \\
\hline
\end{tabular}

Profielen van studenten op basis van hun doeloriëntatie

Het R-pakket MClust vergelijkt de verschillende clustermogelijkheden in termen van aantal clusters en hun vorm, volume en oriëntatie en bepaalt op basis van het Bayesian Information Criterion de optimale clusteroplossing. De latente profielenanalyse op deze data gaf aan dat twee ellipsvormige clusters met een gelijke vorm, gelijk volume en gelijke oriëntatie de beste oplossing was. In figuur 1 worden de gemiddelde scores op de motivatiedimensies weergegeven voor elk van de twee onderscheiden motivatieclusters of motivatieprofielen. Een meerderheid van studenten is verzameld in cluster $1(n=358)$ en beschikt over een motivatieprofiel waarin zowel prestatiegerichte als leergerichte doelen belangrijk zijn. Een minderheid van studenten is verzameld in cluster $2(n=58)$ en beschikt over een motivatieprofiel waarin voornamelijk leergerichte doelen belangrijk zijn. 


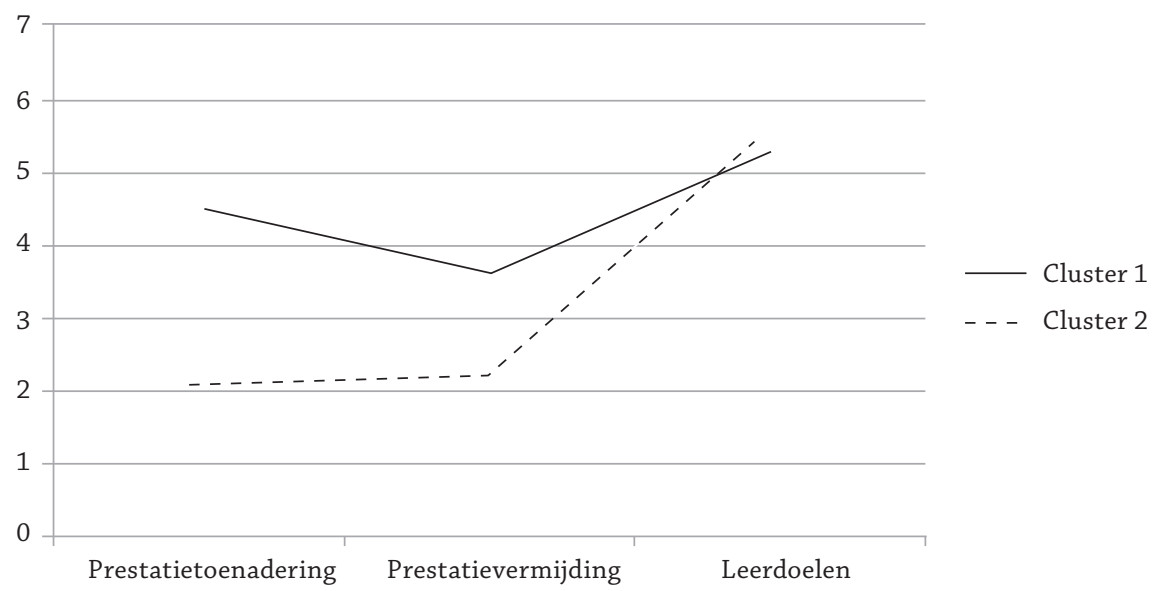

Figuur 1 Profielen doeloriëntatie

Verschillen in werkplekleren

Hoofdeffect afstudeerrichting

Uit de ANOVA-analyses blijkt dat studenten van de verschillende afstudeerrichtingen op diverse gebieden verschillen op het vlak van stageleren (tabel 2).

\section{Tabel 2 Verschillen tussen afstudeerrichtingen}

\begin{tabular}{|c|c|c|c|c|c|c|}
\hline \multirow[t]{2}{*}{ Schaal } & \multicolumn{2}{|c|}{$\begin{array}{l}\text { Kleuter } \\
\text { onderwijs }\end{array}$} & \multicolumn{2}{|c|}{$\begin{array}{l}\text { Lager } \\
\text { onderwijs }\end{array}$} & \multicolumn{2}{|c|}{$\begin{array}{l}\text { Secundair } \\
\text { onderwijs }\end{array}$} \\
\hline & $M$ & $S D$ & $M$ & $S D$ & $M$ & $S D$ \\
\hline \multicolumn{7}{|l|}{ Concepties } \\
\hline Lesgeven en proberen & 5.14 & .71 & 5.26 & .68 & 5.02 & .75 \\
\hline Zelfbepaling & 5.01 & .59 & 3.53 & 1.01 & 3.57 & 1.05 \\
\hline Externe controle & 3.65 & 1.10 & 5.09 & .52 & 4.87 & .52 \\
\hline \multicolumn{7}{|l|}{ Activiteiten } \\
\hline $\begin{array}{l}\text { Proactief, breed gebruik van de men- } \\
\text { tor }\end{array}$ & 5.67 & .89 & 5.57 & .77 & 5.19 & .81 \\
\hline $\begin{array}{l}\text { Onafhankelijk zoeken naar concep- } \\
\text { tuele informatie }\end{array}$ & 4.40 & 1.05 & 3.97 & I.II & 3.85 & 1.06 \\
\hline Actief theorie en praktijk relateren & 5.10 & 91 & 4.75 & .83 & 4.83 & .25 \\
\hline Ontwikkelen visie d.m.v. discussie & 3.13 & 1.30 & 3.04 & 1.32 & 3.54 & 1.28 \\
\hline Leerlinggerichte evaluatiecriteria & 5.59 & .91 & 5.93 & .63 & 5.79 & .74 \\
\hline \multicolumn{7}{|l|}{ Emotieregulatie } \\
\hline Vermijding & 1.81 & .70 & 1.83 & .69 & 2.10 & .82 \\
\hline Bezorgdheid & 4.76 & 1.24 & 4.94 & 1.14 & 4.65 & 1.22 \\
\hline
\end{tabular}


Wat de concepties betreft, valt op dat studenten in de afstudeerrichting secundair onderwijs lager scoren op 'lesgeven en proberen' $(F(2,385)=3.67, p<.05$, $\eta 2$ $=.02)$ en 'externe controle' $(F(2,397)=5.29, p<.01, \eta 2=.03)$ in vergelijking met hun collega-studenten lager onderwijs. Er zijn ook verschillen op het vlak van cognitieve en regulatieve activiteiten. Toekomstige leerkrachten secundair onderwijs doen minder een beroep op hun mentor in vergelijking met de andere twee afstudeerrichtingen $(F(2,388)=7.22, p<.001, \eta 2=.05)$, maar ze stappen wel meer naar hun collega's toe dan de studenten in de afstudeerrichting lager onderwijs $(F(2,394)=4.64, p<.05, \eta 2=.03)$. Studenten van de afstudeerrichting kleuteronderwijs gaan dan weer meer onafhankelijk op zoek naar conceptuele informatie in vergelijking met de andere twee studierichtingen $(F(2,389)=10.59, p<.001$, $\eta 2=.05)$. Ze relateren theorie en praktijk meer aan elkaar $(F(2,395)=4.67$, $p<.01, \eta 2=.02)$ en hanteren minder leerlinggerichte evaluatiecriteria $(F(2,396)$ $=5.71, p<.01, \eta 2=.03$ ) dan studenten in de afstudeerrichting lager onderwijs. Tot slot, stellen we vast dat studenten in het secundair onderwijs hoger scoren op 'vermijding' dan hun collega-studenten van de andere afstudeerrichtingen $(F(2,392)=5.51, p<.01, \eta 2=.03)$. Alle gemiddelde scores en standaardafwijkingen per afstudeerrichting zijn weergegeven in tabel 2. Wanneer er twee gemiddelde scores vet zijn aangeduid, betekent dit dat deze twee scores significant van elkaar verschillen, wanneer één gemiddelde vet staat betekent dit dat dit gemiddelde significant verschilt van de andere twee afstudeerrichtingen.

Hoofdeffect motivatieprofielen

In een volgende stap werd de samenhang tussen motivatieprofielen en kenmerken van leren onderwijzen verkend. In tabel 3 worden enkel de schalen weergegeven waar significante verschillen tussen motivatieprofielen werden vastgesteld (tabel 3).

Wat de leerconcepties van de studenten betreft tonen de resultaten aan dat studenten in de cluster met een combinatie van prestatie- en leerdoelgerichtheid, leren onderwijzen meer zien als lesgeven en proberen $(F(1,385)=14.03, p<.001$, $\eta 2=.03)$. In tegenstelling tot de verwachting scoren deze studenten wel significant hoger voor zelfbepaling in vergelijking met leerdoelgerichte studenten $(F(1,400)=7.01, p<.01, \eta 2=.02)$. Op het gebied van leeractiviteiten zijn de verschillen tussen beide clusters beperkt. Enkel het hanteren van leerlinggerichte criteria verschilt significant. Studenten die een combinatie van doelen vertonen, evalueren hun eigen lesgeven meer op basis van de vooruitgang en motivatie van leerlingen dan studenten die gericht zijn op leerdoelen $(F(1,396)=3.98, p<.05$, $\eta 2=.004)$, maar het statistisch verschil is beperkt te noemen. Tot slot blijkt dat studenten met een combinatie aan doelen hoger scoren op bezorgdheid dan de leerdoelgerichte studenten $(F(1,396=10.08, p<.01, \eta 2=.02)$. 
Eva Kyndt, Vincent Donche, David Gijbels, Eveline Mertens \& Peter Van Petegem

Tabel 3 Significante verschillen tussen motivatieprofielen

\begin{tabular}{lllll}
\hline Schaal & \multicolumn{2}{l}{$\begin{array}{l}\text { Cluster I Prestatie- en } \\
\text { leerdoelgericht }\end{array}$} & \multicolumn{2}{l}{$\begin{array}{l}\text { Cluster 2 Voornamelijk } \\
\text { leerdoelgericht }\end{array}$} \\
& M & SD & M & SD \\
\hline $\begin{array}{l}\text { Concepties } \\
\text { Lesgeven en proberen }\end{array}$ & 5.18 & .70 & 4.80 & .77 \\
$\begin{array}{l}\text { Zelfbepaling } \\
\text { Activiteiten }\end{array}$ & 3.61 & 1.00 & 3.22 & 1.10 \\
$\begin{array}{l}\text { Leerlinggerichte evaluatiecriteria } \\
\text { Emotieregulatie }\end{array}$ & 5.86 & .69 & 5.65 & .83 \\
\begin{tabular}{l} 
Bezorgdheid \\
\hline
\end{tabular} & 4.84 & 1.19 & 4.29 & 1.20 \\
\hline
\end{tabular}

Interactie-effect afstudeerrichting en motivatieprofielen

Er werden geen significante verschillen gevonden voor de interactie tussen de afstudeerrichting en motivatieprofielen met betrekking tot de leerconcepties en emotieregulatiestrategieën. Bij de leeractiviteiten werden twee significante interactie-effecten geïdentificeerd. Met betrekking tot proactief gebruik van de mentor $(F(2,388)=3.36, p<.05, \eta 2=.02)$ blijkt dat studenten met een leerdoeloriëntatie in de afstudeerrichting secundair onderwijs minder beroep doen op hun mentor $(M=4.92, S D=.81)$ dan de studenten met een combinatie aan leerdoelen in de afstudeerrichtingen lager $(M=5.52, S D=.77)$ en kleuteronderwijs $(M=5.59, S D=.88)$. Daarnaast doen studenten met een combinatie van doelen in de afstudeerrichting secundair onderwijs minder beroep op hun mentor $(M=5.23, S D=.81)$ dan leerdoelgerichte studenten in de afstudeerrichting lager onderwijs $(M=5.92, S D=.62)$.

Voor 'ontwikkelen van een visie door middel van discussie' $(F(2,394)=4.24$, $p<.04, \eta 2=.02$ ) werd enkel een significant verschil gevonden tussen studenten met een combinatie aan doelen in de afstudeerrichting secundair onderwijs $(M=3.55, S D=1.23)$ en studenten met een combinatie aan doelen in het lager onderwijs $(M=3.00, S D=1.31)$. In overeenstemming met het hoofdeffect scoren de studenten uit de richting secundair onderwijs hoger.

\section{Conclusie}

De resultaten van deze studie benadrukken dat kwalitatieve verschillen in stageleren kunnen worden onderscheiden. Ze bevestigen tevens de relevantie van het model ontwikkeld door Oosterheert (2001) om deze verschillen in praktijkleren meer systematisch en op verschillende niveaus (leerconcepties, leeractiviteiten en emotieregulatie) te kunnen duiden. In deze studie gaven studenten aan dat ze hun praktijkleren in belangrijke mate laten beïnvloeden door de verschillende actoren in de stageomgeving. Er wordt veel beroep gedaan op hun mentor en collega's en ze houden rekening met reacties van leerlingen om hun eigen prestaties te evalueren. De leerconceptie 'lesgeven en uitproberen' staat centraal. Dit houdt 
enerzijds mogelijk verband met een waardering voor de praktijkcomponenten in de opleiding. Anderzijds kan het een signaal zijn dat het nut van de theoretische lessen onderschat wordt. Verschillende studenten geven echter wel aan dat ze de theorie actief aan de praktijk proberen te koppelen. Voorts wijzen de resultaten uit dat studenten hun negatieve leservaringen niet als een bron van informatie beschouwen, maar zich hier vooral zorgen om maken. Over het algemeen blijken de leerconcepties en de leeractiviteiten die verwijzen naar zelfsturend leergedrag minder op de voorgrond treden. Eerstejaarsstudenten in de lerarenopleiding lijken liever aangestuurd te worden door anderen dan zichzelf.

Het onderzoek naar het verband tussen enerzijds het type lerarenopleiding en anderzijds het motivatieprofiel in relatie met leren leverde belangrijke inzichten op. Er worden meer verschillen in stageleren vastgesteld op basis van de afstudeerrichting dan aan de hand van de motivatieprofielen (al dan niet in interactie met de afstudeerrichting). Studenten in de afstudeerrichting kleuteronderwijs scoren hoog op de leeractiviteiten waarbij ze onafhankelijk zoeken naar conceptuele informatie die ze dan actief gaan relateren aan hun praktijkervaring. Verder maken ze minder gebruik van leerlinggerichte criteria dan studenten uit de afstudeerrichting lager onderwijs. Gezien de jonge leeftijd van de kleuters is dit misschien geen verrassend resultaat. Studenten uit de afstudeerrichting lager onderwijs beschouwen het leren onderwijzen meer dan de studenten uit de andere studierichtingen als 'het uitproberen van lesgeven'. Ook deze studenten worden vooral graag aangestuurd door anderen dan zichzelf. Studenten uit de afstudeerrichting secundair onderwijs doen minder een beroep op hun mentor maar stappen sneller naar hun collega's op de werkplek in functie van het leren onderwijzen. Dit resultaat kan verklaard worden uit het feit dat studenten in de afstudeerrichting secundair onderwijs verschillende opleidingsonderdelen (e.g. economie, Frans) opnemen en hierdoor meer samenwerken met verschillende mentoren (vakleerkrachten). Bijgevolg werken ze slechts een beperkt aantal uren samen met elke mentor. In vergelijking met de andere afstudeerrichtingen waarin de student slechts met één mentor samenwerkt, wordt dus in mindere mate een band opgebouwd tussen de student en de mentor.

Het veronderstelde verband tussen de prestatiedoelentheorie en kenmerken van leren onderwijzen bleek in deze studie minder aan de orde te zijn dan theoretisch werd verondersteld. De twee onderscheiden motivatieprofielen zijn slechts beperkt gerelateerd aan verschillen in leren tijdens stages. Enerzijds zien studenten met het meer leerdoelgerichte profiel lesgeven in mindere mate als uitproberen en richten studenten met dit profiel zich minder op anderen om de eigen prestatie te evalueren. Ze zijn ook in mindere mate bezorgd over hun slechte leservaringen. Anderzijds scoort het profiel dat een combinatie van doelen vertoont hoger op zelfbepaling. Deze resultaten wijzen op een matig verband tussen kenmerken van leren onderwijzen en motivatie zoals gemeten via de prestatiedoelentheorie en noodzaakt vervolgonderzoek naar de rol van motivatie. De resultaten van deze studie sluiten vooral aan bij de bevinding dat het moeilijk blijft om een optimale combinatie van doeloriëntaties te bepalen (Pastor et al., 
2007). Dit heeft mogelijk ook implicaties voor het onderscheiden van betekenisvolle verbanden tussen motivatieprofielen en kenmerken van leren onderwijzen.

Aangezien de verschillen tussen de richtingen sterker samenhangen met verschillen in leren tijdens stages dan de verschillen tussen motivatieprofielen, rijst de hypothese dat verschillen in hoe studenten leren onderwijzen mogelijk nog meer verbonden zijn met specifieke omgevingsfactoren. Toekomstig onderzoek is nodig om te bepalen welke omgevingsfactoren van belang zijn om bijvoorbeeld het meer zelfgestuurd leren van studenten tijdens stages te stimuleren. Voorts is het belangrijk dat er op een positieve wijze aandacht besteed wordt aan slechte leservaringen zodat de studenten hier minder bezorgd over zijn en de leerkansen ervan inzien. Hierbij is een belangrijke rol weggelegd voor de stagebegeleiders en mentoren, opdat een veilige omgeving gecreëerd wordt waarin de student durft te spreken en leren uit zijn fouten.

\section{Praktijkimplicaties}

De resultaten van dit onderzoek zijn ook voor de praktijk relevant. Zo wordt het belang van de mentor en de inbreng van collega's op de werkplek onderstreept. Studenten lijken het veel belangrijker te vinden voldoende sturing en feedback te krijgen van anderen dan zichzelf. Het onderzoek toont ook aan dat niet in alle afstudeerrichtingen studenten een even sterk beroep doen op de mentor. Dit kan verklaard worden vanuit de samenwerkingsintensiteit. In de opleiding 'Bachelor in het onderwijs: kleuter- en lager' lopen studenten, in tegenstelling tot studenten secundair onderwijs, volledige dagen mee in de klas. Ook de duur van de stages in deze opleidingen is langer, met meer kansen voor het ontwikkelen van onderlinge banden. Bovendien blijkt uit navraag in de context van het onderzoek dat in de opleidingen kleuter- en lager onderwijs wordt geopteerd voor schoolstages waarbij een student gedurende een volledig schooljaar aan dezelfde school verbonden is. De student wordt quasi een teamlid en leert de verschillende mentoren ook buiten de klascontext kennen. Uiteraard kan deze band nog extra versterkt worden via het verdiepen van samenwerking tussen lerarenopleidingen en stagescholen.

Deze studie toont ook aan dat studenten op verschillende wijze omgaan met negatieve leservaringen. In de context waarin dit onderzoek plaatsvond, wordt heel wat aandacht geschonken aan stage-ervaringen, waarbij studenten worden gestimuleerd om na te denken wat ze kunnen leren uit negatieve leservaringen. De individuele verschillen die optreden kunnen wijzen op de noodzaak om deze begeleidingspraktijk meer gedifferentieerd toe te passen, maar vervolgonderzoek is noodzakelijk.

Deze studie wijst op een aantal belangrijke individuele verschillen bij eerstejaarsstudenten op het vlak van stageleren en motivatie. Het verstrekken van feedback over deze verschillen op zowel individueel als groepsniveau kan alvast een eerste stap zijn om meer bewustwording bij studenten, maar ook bij mentoren en docenten, te stimuleren. De gehanteerde meetinstrumenten in deze studie bieden 
alvast een perspectief om deze verschillen in kaart te brengen en waar mogelijk in te zetten in functie van begeleiding en onderwijsondersteuning.

\section{Referenties}

Baeten, M., Kyndt, E., Struyven, K., \& Dochy, F. (2010). Using student-centred learning environments to stimulate deep approaches to learning: Factors encouraging or discouraging their effectiveness. Educational Research Review, 5, 243-260.

Berger, J.-L. (2012). Uncovering vocational students' multiple goal profiles in the learning of professional mathematics: differences in learning strategies, motivational beliefs and cognitive abilities. Educational Psychology: An International Journal of Experimental Educational Psychology, 32, 405-425.

Donche, V., De Maeyer, S., Coertjens, L., Van Daal, T., \& Van Petegem, P. (2013). Differential use of learning strategies in first-year higher education: the impact of personality, academic motivation, and teaching strategies. British Journal of Educational Psychology, 83(2), 238-251.

Donche, V., Gijbels, D., Van den Bossche, P., Van Petegem, P., \& Ilsbroux, I. (2011). Individual differences in learning during internships in engineering education. Paper presented at the Biannual Conference of the European Association of Learning and Instruction, Exeter, UK.

Donche, V., \& Van Petegem, P. (2005). Assessing preservice teachers' orientation to learning to teach and preferences for learning environments. Scientia Paedagogica Experimentalis, 42, 27-52.

Donche, V., Verbeke, H., Ilsbroux, I., Sammels, E., Janssen, H.J., \& Van Petegem, P. (2012). Licht op werkplekleren: inzichten vanuit praktijk en onderzoek. In H. Van de Mosselaer, P. Van Petegem, D. van Dijk, \& L. Michiels (red.), Goesting in leren en werken (pp. 211-228). Antwerpen: Garant.

Elliot, A., \& McGregor, H. (2001). A 2x2 achievement goal framework. Journal of Personality and Social Psychology, 80, 501-519.

Endedijk, M.D., Donche, V., \& Oosterheert, I. (2014). Student teachers' learning patterns in school-based teacher education programmes: The influence of person, context and time. In D. Gijbels, V. Donche, J.T.E. Richardson, \& J. Vermunt (Eds.), Learning patterns in higher education: Dimensions and research perspectives (pp.102-122). London: Routledge.

Endedijk, M.D., \& Vermunt, J.D. (2013). Relations between student teachers' learning patterns and their concrete learning activities. Studies in Educational Evaluation. doi: 10.1016/j.stueduc.2012.10.001.

Gijbels, D., Donche, V., Richardson, J.T.E., \& Vermunt, J.D. (2014). Learning patterns in higher education: dimensions and research perspectives. New perspectives on learning and instruction. London: Routledge.

Kyndt, E., Dochy, F., Struyven, K., \& Cascallar, E. (2012). Looking at learning approaches from the angle of student profiles. Educational Psychology, 32, 493-513.

Meece, J., Blumenfeld, P., \& Hoyle, R. (1988). Students' goal orientations and cognitive engagement in classroom activities. Journal of Educational Psychology, 80, 514-523.

Nitsche, S., Dickhäuser, O., Fasching, M.S., \& Dresel, M. (2011). Rethinking teachers' goal orientations: Conceptual and methodological enhancements. Learning and Instructions, 21, 574-586. 
Oosterheert, I. (2001). How student teachers learn. A psychological perspective on knowledge construction in learning to teach. Doctoral dissertation. University of Groningen, The Netherlands.

Oosterheert, I., Vermunt, J.D., \& Denessen, E. (2002). Assessing orientations to learning to teach. British Journal of Educational Psychology, 72, 41-64.

Pastor, D.A., Barron, K.E., Miller, B.J., \& Davis, S.L. (2007). A latent profile analysis of college students' achievement goal orientation. Contemporary Educational Psychology, 32, 8-47.

R Development Core Team (2012). R: A language and environment for statistical computing. R Foundation for Statistical Computing: Vienna, Austria. Geraadpleegd op 19 juli 2012 via http://www.R-project.org/. 